\title{
Rafeeq Hasan \\ Frihed og lykke i Rousseaus retfærdiggørelse af staten
}

\begin{abstract}
Political philosophers tend to think that Rousseau is significant because his contractarianism anticipates Kant. However, reading Rousseau in this way requires us to ignore his frequent and emphatic appeals to the role of happiness as collective flourishing (eudaimonia) in establishing the rational authority of justice. I offer a reading of Rousseau's political theory which accounts for this eudaimonistic aspect of his thought. I argue that for Rousseau, as for Kant, obligations are structured by the autonomous willing of agents who bind themselves by the norms of reason alone. But unlike Kant, Rousseau thinks that such formal considerations of rational autonomy provide necessary but not sufficient reasons for fulfilling our duties to one another. This is because the ultimate reason for valuing individual autonomy is that it enables the flourishing of individuals insofar as they are members of a just political community.
\end{abstract}

Nøgleord

Rousseau, politisk teori, kollektiv lykke, autonomi, retfardighed, Kant

Let us try, therefore, to hypothesize the idea of a happy people, and then we shall establish rules of right on the basis of this idea. - Rousseau, Political Fragments

Moderne politisk filosofi ser to inkompatible tilgange til at retfærdiggøre statens legitimitet. Det alternativ, der hævdes, er mellem et princip om kollektiv lykke og trivsel og et princip om individuel frihed. Det synes særlig tydeligt, at den kontraktualistiske retfærdiggørelse af staten renoncerer på det førstnæunte princip til fordel for det sidstnævnte. Når alt kommer til alt er den eksplicitte opgave, som sådanne projekter sætter for sig selv, at vise, at grunden til, at tvangen fra statens lovgivningsmagt ikke kun repræsenterer arbitrær vold eller moralsk illegitim dominans, er, at en sådan institution ville blive valgt af rationelle individer, der er optaget af at beskytte deres grundlæggende interesser.

Set ud fra vores kontraktualistiske arv kan det synes som om den eneste måde at retfærdiggøre en liberal-demokratisk stat, en der frem for alt er optaget af at beskytte individuelle rettigheder, er ved at insistere på den normativt centrale placering af individuel frihed frem for kollektiv trivsel. ${ }^{1}$ Denne retfærdiggørende strategi synes videre at hænge sammen med en forståelse af retsstaten, blot som et formelt redskab til at beskytte individerne mod hinanden. Dog kunne disse filosofiske resultater muligvis få os til at overveje det fornuftige

1 Jeg er af den opfattelse, at Rawls' adskillelse af det retfærdige fra det gode beror på en prioritering af frihed frem for trivsel. Se A Theory of Justice, 2nd Edition (Cambridge: Harvard University Press, 1999, 27-33).

Rafeeq Hasan, University of Chicago, USA

E-mail: rahasan@uchicago.edu

Studier i Pcedagogisk Filosofi | www.ojs.statsbiblioteket.dk/index.php/spf | ISSN nr. 22449140

Årgang 3 | Nr. 1 | 2014 | side 71-94 
i vor troskab mod en stat, der i bedste fald anser muligheden for at realisere vor kollektive natur som et tilfældigt biprodukt frem for et centralt mål, og i værste fald, en form for potentiel ufrihed eller herredømme, som vi til stadighed må arbejde på at redde os selv fra. ${ }^{2}$

I denne artikel hævder jeg, at en af de centrale historiske personer inden for den rettighedsbaserede kontraktteoretiske politiske filosofi, Jean-Jacques Rousseau, ikke oplevede en dikotomisk spænding mellem kollektiv trivsel og individuel frihed. På grund af dette tilbyder hans politiske tænkning en konceptuelt stærk og normativ tiltrækkende metode til at retfærdiggøre den demokratiske, rettighedsbeskyttende stat. Jeg foreslår, at Rousseau argumenterer for et internt eller gensidigt konstituerende forhold mellem den frie rationelle autonomi hos individer og den lykke eller trivsel, som hidrører fra deltagelse i et retfærdigt politisk fallesskab. I Rousseaus vision om et velordnet samfund er borgerne kun individuelt frie, hvis de kollektivt trives. Samtidig er det dog et nødvendigt kriterium for deres kollektive trivsel, at enhver indrømmes de rettigheder og fordringer, der hidrører fra deres individuelle frihed. I denne henseende gør retsstaten det muligt for et folk at leve sammen i harmonisk fællesskab, uden dermed at krænke individets interesser for en organisk helheds skyld.

For at kunne være på det rene med, at dette faktisk er Rousseaus syn på grundlaget for statens legitimitet, må vi udfordre den fremherskende fortolkning af hans politiske filosofi inden for den anglo-amerikanske filosofiske verden. Den Sociale Autonomi-tolkning (herefter SA) ved Rawls, Joshua Cohen, Nicholas Dent og Frederick Neuhouser kan ikke acceptere den retfærdiggørende rolle, som spilles af den kollektive lykke, og må i visse centrale henseender derfor opgives. ${ }^{3}$ Denne anklage vil jeg udfolde nedenfor.

\subsection{Individuel autonomi og kollektiv trivsel}

Mange af de kommentatorer, som associeres med SA, beskæftiger sig med at knytte Rousseau an til en kantiansk og post-kantiansk udvikling i politisk filosofi. Svarende hertil forstår de Samfundspagten som sigtende efter at retfærdiggøre den demokratiske, rettighedsbeskyttende stat på det grundlag, at kun den kan sikre frihed, forstået som rationel autonomi, eller mere bredt, som individets evne til at kunne leve uhindret af diktater fra

2 For en uddybning af denne bekymring se Michael Sandel, Liberalism and the Limits of Justice, 2nd edition. (Cambridge: Cambridge University Press, 1998).

3 De vigtigste værker om SA, jeg her citerer, er: Joshua Cohen, Rousseau: A Free Community of Equals [Free Community] (Oxford: Oxford University Press, 2010). Frederick Neuhouser, Foundations of Hegel's Social Theory: Actualizing Freedom [Foundations], (Cambridge: Harvard University Press, 2003), og Rousseau's Theodicy of Self-Love: Evil, Rationality, and the Drive for Recognition [Rousseau's Theodicy] (Oxford: Oxford University Press, 2008). John Rawls, Lectures on the History of Political Philosophy [Lectures]. ed. Samuel Freeman (Cambridge: Harvard University Press, 2007); og Nicholas Dent, Rousseau: An Introduction to his Psychological, Social and Political Theory [Rousseau] (London: Blackwell, 1989). Jeg behandler også Maurizio Viroli, Jean-Jacques Rousseau and the Well-Ordered Society [Well-Ordered Society] trans. Derek Hanson (Cambridge: Cambridge University Press, 2003) and Ernst Cassirer, The Question of Jean-Jacques Rousseau [Question] trans. Peter Gay (New Haven: Yale University Press, 1989) som vigtige foregribelser vedrørende mange af de aspekter af SA, som jeg forholder mig til her. 
nogen andens vilje end sin egen. For eksempel skriver Frederick Neuhouser: "Retfærdiggørelsen af den fornuftige stat er indeholdt i det faktum, at en sådan stat spiller en uundværlig rolle i konstitueringen af mennesker som bærere af frie viljer, og den er derfor essentiel for fuldbyrdelsen af deres sande natur som frie væsener"' . Og Ernst Cassirer bemærker noget kryptisk, at det er med Samfundspagten, at "vejen til frihed ligger åben" for efterfølgende udviklinger af filosofien om staten. ${ }^{5}$

Neuhouser og Cassirer har uden tvivl ret i at frihed spiller en central rolle i Rousseaus argument for statens legitimitet. Rousseau signalerer frihedens centrale betydning for dette emne med sin beskrivelse af det "fundamentale problem", for hvilket kontrakten er den eneste løsning: "At finde en form for sammenslutning, som vil forsvare og beskytte hver enkelt medlems person og ejendele med hele den fælles magt, og hvorigennem hver enkelt ved at forene sig med alle alligevel kun adlyder sig selv og forbliver lige så fri som førhen" (SC, 1.6.4) (min kursivering). ${ }^{6}$ I et elegant sammendrag af følgerne af Samfundspagten, argumenterer Rousseau, at lovens fornuftsmæssige autoritet hidrører det faktum, at den muliggøre en autonom frihed som en formel løsning på dette "fundamentale problem". Han skriver: "Man er fri selvom man er underkastet love, og ikke når man adlyder et menneske, fordi jeg i det sidste tilfælde adlyder en andens vilje, men når jeg adlyder loven, så adlyder jeg kun den offentlige vilje, som er min lige så meget som enhver andens" (PF, 28) (min kursivering).

Sådanne passager indikerer, at frihed både er problemet for og løsningen på Rousseaus politiske filosofi som helhed. Den sociale kontrakt er som bekendt et forsøg på at redde individets usikre frihed under omstændigheder, hvor nødvendigheden af socialt samvirke har placeret alle i relationer med friheds-truende afhængighed. Rousseaus overraskende forslag er, at den eneste måde hvorpå alle kan forblive fri af sådanne ulidelige afhængighedsrelationer er for enhver at ville en stat, hvis højeste tvingende kræfter kun udøves gennem alment bindende love, der beskytter alles fundamentale interesser. Men såfremt enhver agent aktivt har villet en sådan stat, så bliver de love som bestemmer over ham udtryk for hans egen vilje. Kontrakten afslører således, at den eneste måde at være fri fra afhængighed af andre er at være indre styret af ens egen rationelle vilje og således at være autonom. Eller som Rousseau skriver, "lydighed mod en lov, som man selv har foreskrevet sig", det vil sige frihed som rationel autonomi, er blandt de centrale gevinster i den borgerlige tilstand (SC, 1.8.3/OC III, 365)?

Men samtidig med at Rousseau lokaliserer grundlaget for vores rationelle troskab mod staten ud fra den autonomi, som konstitueres heri, argumenterer han også for, at statens

4 Neuhouser, Foundations, 56-57.

5 Cassirer, Question, 54 (fremhævet i originalen).

6 Rousseaus værker er blevet betegnet med forkortelser sidst I denne tekst. Når jeg har refereret til de originale franske værker, har jeg også angivet bind og sidetal I Oeuvres Complètes [OC]. Referencer til den Sociale Kontrakt [SC] er til bog, kapitel og afsnit.

7 Rousseau antyder også, at fordi forpligtelser bygger på autonomi, skal de virkelig være frit selvlovgivet af agenten selv, idet han skriver, at forpligtelse ikke kan have et "mere sikkert fundament...end det frie engagement hos den der forpligter sig selv". (LM, 231). 
legitimitet udspringer fra den rolle, den spiller i at muliggøre kollektive former for lykke eller trivsel. Mens han således umiddelbart tilbyder en formel redegørelse for statens legitimitet, indskyder Rousseau kontinuerligt kommentarer, der vedrører dens borgeres lykke. Borgere $i$ et velordnet samfund antages vedvarende "at ville enhvers lykke" (SC, 2.4.5), fordi "den fælles lykke udgør en mere betydelig del af hvert individs lykke" (SC, 3.15.3). Endnu stærkere argumenterer Rousseau, at offentlig lykke er "kilden" til "de private individers lykke" (le bonheur des particuliers) (GM, 160/OC III, 284).

I det mindste i sine politiske skrifter gør Rousseau det tydeligt, at den form for lykke, der er tale om, ikke blot er subjektiv eller et spørgsmål om privat følelse $(\mathrm{fx} P F, 40-41){ }^{8}$ Så ved kontinuerligt at referere til borgerlig 'lykke' hævder Rousseaus ikke, at staten muliggør en følelse af opstemthed, som kommer af ikke at skulle give agt på en herres råb. Med disse påkaldelser om lykke synes Rousseau snarere at placere statens normative validitet i den kendsgerning, at den tillader essentielle menneskelige evner at trives, evner som er helt igennem sociale. Eksempelvis skriver han, at staten er essentiel "for udviklingen af vore mest fremragende evner", som paradigmatisk er evnerne for rationel handling og identifikation med andre på vilkår præget af gensidighed og respekt (GM, 159). På denne måde forandrer den mennesket fra at være "et stupidt og bundet dyr" til at være "et intelligent væsen og et menneske" (SC, 1.8.1).

På visse områder forbinder Rousseau direkte legitimeringen af statens tvingende magt med lykke, snarere end med frihed. Han skriver at "tvang er kun et middel; dets mål er folkets lykke" (PF, 40). Ligeledes kontrasterer han lejlighedsvis legitime og illegitime politiske samfund, ikke, som man kunne forvente det, i forhold til om de beskytter (eller muliggør) individuel autonomi eller ej, men snarere i henseende til det førstnævntes "mål om fæelles lykke fra hvilken hvert individ vil aflede sin egen" (GM, 158). I hvad der muligvis er hans stærkeste udtalelse om lykkens forrang frem for frihed, argumenterer Rousseau, at man først må "hypotetisere ideen om et lykkeligt folk" og først derefter "etablere regler om rettighed på baggrund af denne idé" (PF, 40). ${ }^{9}$ Baseret på sådanne påstande, kan det virke som om den rousseauske stat er legitimeret fordi den, ved at virkeliggøre menneskelig natur, tillader mennesket at trives som det, det essentielt er: en deltager i et kooperativt hele.10

8 For fortolkninger af Rousseaus opfattelse af lykke som psykologisk og essentielt subjektiv se Arthur Melzer, The Natural Goodness of Man: On the System of Rousseau's Thought (Chicago: University of Chicago Press, 1990), 38-46, 64-68; Laurence Cooper, Rousseau, Nature and the Problem of the Good Life (University Park, Pennsylvania: The Pennsylvania State University Press, 1999), 19-29; og Leo Strauss, Natural Right and History (Chicago: University of Chicago Press, 1953) , 291-293. Uanset hvilke fortjenester sådanne fortolkninger måtte have for tekster som, for eksempel the Reveries of the Solitary Walker, så berører de ikke fundamentet for Rousseaus politiske værker, eller som jeg kort diskuterer nedenfor, for Émile.

9 Den franske udgave nævner kun "regler" [règles], og ikke "rettighedernes regler", men jeg mener at den sidste benævnelse er berettiget ud fra en helhedsforståelse af passagen (se OC III, 509).

10 For læsninger af denne type, se Sergio Cotta, "La Position du Probème de la Politique Chez Rousseau," in Études sur le Contrat Social de Jean-Jacques Rousseau (Dijon: L'Université de Dijon, 1964), Robert Derathé, “L’Homme Selon Rousseau," in Études sur le Contrat Social de Jean-Jacques Rousseau 206-207, og Émile Durkheim, Montesquieu and Rousseau: Forerunners of Sociology (Michigan: University of Michigan Press, 1960). 
I det følgende vil jeg give et bud på en ny fortolkning af de normative grundlag for Rousseaus politiske teori, med det formål at komme til en forståelse af, hvordan både individuel autonomi og kollektiv trivsel kan fungere sammen som retfærdiggørelser af staten. Ifølge den model jeg foreslår - og som jeg vil referere til som Rousseaus dobbelte retfærdiggørende struktur (DRS) - tænker Rousseau, at autonom frihed og kollektiv lykke er medkonstituerende. Hensyn til autonomi kan forklare vores troskab mod staten, fordi autonomi muliggør kollektiv trivsel. Alligevel kan en hvilken som helst ægte vision om fælles trivsel ikke begrebsligt adskilles fra den individuelle autonomis rettigheder. Sagt på en anden måde: mens Rousseau viser, at grundlaget for vores troskab til staten stammer fra et frit, autonomt og rationelt virkes nødvendige forpligtigelser, binder han samtidig værdien og den retfærdiggørende kraft af rationel autonomi sammen med dens rolle som en nødvendig komponent i kollektiv menneskelig trivsel.1

\subsection{Kantianske kritikker}

For at kunne værdsætte betydningen af Rousseaus DRS, må i først at se på, hvorfor frihed og lykke overhovedet kan synes at være i et spændingsforhold. Det er fra Kant, at angloamerikansk politisk filosofi har arvet sin opfattelse af inkompatibiliteten ved disse to normative idealer. (Det burde derfor ikke komme som nogen overraskelse, at tidligere tænkere så som Rousseau ikke bekymrer sig om nogen formodet inkonsistens ved at referere, skiftevis, til frihed og til lykke). Kants bevæggrunde for at insistere på denne inkompatibilitet er ekstremt komplekse. På det dybeste niveau angår de en skelnen mellem autonome og heteronome anvendelser af den praktiske fornuft, som ikke har meget at gøre med Rousseaus mere klart politiske projekt. ${ }^{12}$ For vort forehavende er det derfor mest relevant at formulere Kants pointe med reference til rettigheder.

For Kant er den nødvendige konsekvens af at tillade lykke at spille en rolle i retfærdiggørelsen af staten, at det bevirker, at de individuelle autonome rettigheder bliver ikkeabsolutte og ustabile. Det forholder sig således, på trods af at den fremsatte opfattelse af lykke er direkte optaget af betingelserne, hvorunder enhver agent kan opnå sit største sociale potentiale. Kants argumentation for dette er som følger: (1) Hvis man accepterer, at retfærdiggørelse af staten hviler på det faktum, at den muliggør min evne til ikke at adlyde andre viljer end min egen, så må man dermed også acceptere at dette hensyn trumfer enhver Henvisning til fremstilling af den kollektive nytte eller trivsel, fordi det altid må være

11 Igennem hele denne afhandling behandler jeg som dele af en samlet helhed tre emner, som samtidige kontraktualistiske filosoffer holder adskilt (f.eks. Rawls, Lectures, 15): (1) En opfattelse om politisk legitimitet, (2) en forståelse af borgeres retligt tvingende forpligtelser overfor staten; og (3) en forståelse af borgeres (ikke-tvingende) moralske forpligtelser overfor hinanden som medlemmer af staten. Selvom jeg starter med at diskutere (1), ender jeg med (2) og (3). Jeg mener at min fremgangsmåde er retfærdiggjort, i og med Rousseau selv behandler dem som indbyrdes udskiftelige.

12 Om fraværet af noget som helst hos Rousseau, der bare tilnærmelsesvis ligner Kants forståelse af praktisk fornuft, se Richard Velkley Freedom and the End of Reason: On the Moral Foundations of Kant's Critical Philosophy (Chicago: University of Chicago Press, 1989). 38. 
op til mig selv at bestemme, hvorvidt jeg bør interessere mig for sådanne mål. ${ }^{13}$ (2) Så hvis man fastholder, at statens tvingende kraft er baseret på lykke, er man implicit bundet til den påstand, at en agent kan blive tvunget til at adlyde normer, som potentielt ikke er andet end en anden viljes krav (fordi den ikke er godkendt af agenten selv). (3) Men i det tilfælde vil enhver faktisk reference til rettighedskrav på vegne af en lykkebaseret stat, blot være instrumentel. Fordi rettigheder $i$ en sådan stat blot tjener som anvendelige metoder til det ydre definerede mål for lykke. Dette mål er ydre defineret fordi det, som vi netop har set, mangler moralsk indhold og det moralske indhold mangler, fordi det lykkefremmende mål tilsyneladende er i overensstemmelse med sager hvor en agent med tvang bestemmer betingelserne for andre (en anden måde at sige dette på er, at opfattelserne af lykke bør være reguleret af moralitet, netop fordi de ikke er moralske i sig selv). (4) På den anden side følger det heraf, at hvis vi lever i en stat, der retfærdiggør sin magt baseret på kollektiv lykke, vil de rettigheder vi faktisk antager, at vi på et givent tidspunkt har, i sidste ende være baseret på intet mere solidt end den øjeblikkelige forestilling om lykke, som er fremherskende hos det styrende organ. ${ }^{14}$ I en lykkebaseret stat er rettigheder kontingente alt efter despotens velvilje; de mangler et grundlag i autonom fornuft overhovedet.

Mens Kant behandler lykke som en subjektiv tilstand, idet han skriver, at "enhver må søge sin egen lykke således som det forekommer ham gavnligt ",15 har jeg foreslået, at for Rousseau henviser lykke til de objektive betingelser, under hvilke mennesket kan erkende sin natur som et socialt væsen. Hvis vi, ikke desto mindre, ser bort fra denne terminologiske instabilitet, er den grundlæggende forskel mellem disse to tænkere tydelig. Som vi allerede har set, knytter Rousseau til tider statens legitimitet til dens rolle som en kanal for fælles trivsel - staten modtager sin rationelle kraft fra dens evne til at muliggøre "den forbundenhed [liason] mellem delene som konstituerer helheden". Hvorimod Kant argumenterer, at for at kunne bevare de autonome rettigheder, kan staten ikke foretage henvisninger til sådanne naturligt delte kollektive mål, og kan således ikke være betinget af en vision om kollektiv trivsel overhovedet. ${ }^{16}$

Det er ikke svært at formulere den samme grundlæggende bekymring i termer, der ikke eksplicit henviser til Kant. Ved at sammenstille Rousseaus påberåbelse af individuel frihed og kollektiv lykke, bør vi stille den følgende type spørgsmål: Åbner den rousseauske stat for muligheden af, at ethvert individ kun adlyder sig selv, ved at tillade en form for flugt fra vores menneskelige afhængighed af andre personer? Med andre ord, eksisterer den "offentlige magt" kun for at beskytte "individuel svaghed" (DPE, 17)? Eller det er staten, som udvikler mennesket til det gennemgribende afhængige, konstitutivt sociale væsen, som det

13 Se Immanuel Kant. "On the Common Saying: 'That may be correct in theory, but it is of no use in practice'” in Kant: Practical Philosophy, trans. Mary Gregor and Allen Wood (Cambridge: Cambridge University Press, 1996), især Ak: 290-298. For en udvidet udarbejdelse af betydningen af denne basale kantianske idé for nutidig politisk tænkning, se Arthur Ripstein, Force and Freedom: Kant's Legal and Political Philosophy (Cambridge: Harvard University Press, 2009).

"On the Common Saying", AK 8: 290. 
er, således at inden for staten er individer "kun forbundet med hinanden fordi de er knyttet til samfundet". ${ }^{17}$ Kort sagt, peger Samfundskontrakten fremad mod Rechtsstaat eller peger den tilbage mod den græske polis? ${ }^{18}$

Kommentatorer, som er associeret med SA, har forsøgt at etablere Rousseaus gode kantianske kvalifikationer ved at svare med et utvetydigt 'ja' til det første sæt af muligheder og et tilsvarende utvetydigt 'nej' til det andet. Dette har taget form af et ønske om at ignorere, nedtone eller radikalt omfortolke betydningen af Rousseaus bemærkninger om kollektiv lykke. På den ene side af SA spektret står Cassirers fuldstændige benægtelse af denne tematik: "Rousseau krævede ikke af det menneskelige samfund, at det skulle øge menneskets lykke... men at det skulle sikre hans frihed og på denne måde genoprette ham til sin sande skæbne ". ${ }^{19}$ Jeg bruger begrænset tid på at adressere Cassirers påstand, eftersom det står i så indlysende i modstrid med de passager, der er citeret ovenfor. ${ }^{20}$

Det spor af SA, som jeg egentlig ønsker at overveje i det følgende, bestrider ikke den åbenlyse tekstuelle pointe, at Rousseau ofte bruger et eudaimonistisk sprog, men det foreslår, at henvisningerne til begreber som lykke og trivsel relaterer til det angiveligt uafhængige tema om politisk stabilitet. Ved at tale om lykke anses Rousseau for at tilkendegive en bekymring for, om et politisk system sætter sine undersåtter i stand til at bære vægten af deres forpligtelser uden et tungt, splittet hjerte. Det velordnede samfund i Samfundskontrakten er således 'lykkeligt' for så vidt, at det fremmer de kommunitaristiske psykologiske dispositioner, som kan anspore agenter til at opretholde den liberale legitimitets grundlæggende principper. Hensyn til trivsel motiverer simpelthen hensyn til frihed, hvilket er det der gør det virkelige retfærdiggørende arbejde. Eksempelvis skriver Joshua Cohen, "[Rousseaus] stærke påstande om behovet for... fælles lykke som en ingrediens i individuel lykke er fremsat... som betingelse for stabiliteten af et legitimt system, ikke som konstitutive elementer af selve begrebet om legitimiteten." ${ }^{21}$ I Cohens lys, spiller Rousseaus dragning mod borgerlig lykke ikke nogen normativ rolle i legitimering af staten.

17 Durkheim, Montesquieu and Rousseau, 112.

18 Om den gennemgribende individualisme i Rousseaus retfærdiggørelse af staten, se Judith Shklar, Men and Citizens: A Study of Rousseau's Social Theory (Cambridge: Cambridge University Press, 1985), 16-17. For en modsat reaktion, se Jacob Talmon, The Origins of Totalitarian Democracy (New York: Norton, 1970). For formuleringer, der anklager Rousseau som vaklende (inkohærent) mellem et antikt og moderne syn på politisk fællesskab, se C.E. Vaughan, "Introduction" (ed). The Political Writings of Jean-Jacques Rousseau, 2 vols. (Cambridge: Cambridge University Press, 1915), 5, og Viroli, Well-Ordered Society, 131, 220-221.

19 Cassirer, Question, 105-106.

20 Under alle omstændigheder ophæver Cassirer senere dette, ved at skrive "som hvis en eudaimonist [Rousseau] passioneret bestræbte sig på at skabe menneskelig lykke, var han forpligtet til at acceptere mere og mere klart, at bestræbelsen ville være forgæves, så længe 'menneskets rettigheder' var usikre". Cassirer, Rousseau, Kant, Goethe, trans. James Gutmann, Paul Oskar Kristeller, and John Herman Randall, Jr. (New York: Harper, 1963), 27. Da det ville føre mig for langt væk fra emnet, at vurdere Cassirers påstand I forhold til DRS, må det være tilstrækkeligt at påpege, at her forstår Cassirer lykke og ret som eksternt relateret, således at lykke er et ikke-moralsk specificeret mål som moralitet efterfølgende regulerer eller begrænser. Dette er stadig alt for kantiansk til at kunne indfange den gensidige konstitutive relation mellem frihed og trivsel i Rousseaus DRS.

21 Cohen, Free Community, 57 (min kursivering). For en lignende todeling af normativ legitimitet og psykologisk motivation se Rawls, Lectures, 193, 206-207, 214-215, 237-241; Neuhouser, Foundations, 190-192, og Viroli, Well-Ordered Society, 13, 212-213. 
Jeg argumenterer udførligt mod denne fortolkning, fordi den bedste måde at belyse, hvad jeg antager som værende Rousseaus faktiske syn på den indre relation mellem frihed og trivsel, er ved at forstå dens fejltagelser. Ved at insistere på denne indre forbindelse viser DRS, at kollektiv politisk trivsel afhænger af ukrænkeligheden af individuelle rettigheder. Således er den uberørt af Kants kritik af lykkebaseret legitimering af staten.

I argumentationen for disse påstande, fortsætter jeg som følger: I anden del diskuterer jeg et fortolkningsmæssig problem angående kollektiv lykke og politisk transformation i Samfundskontrakten, og jeg kritiserer SAs løsning på dette problem. I tredje del vil jeg gradvist udvikle DRS som en mere tilfredsstillende løsning på problemet. I den afsluttende del fremsætter jeg bemærkninger om, hvordan min fortolkning af lykkens rolle i Rousseaus legitimering af staten stemmer overens med andre aspekter af hans tanker - navnligt, (1) hans påstand om at frihed er det menneskelige gode, (2) hans behandling af amour propre, eller lysten til at blive anerkendt af andre og (3) hans diskussion af almenviljen. Jeg optegner også de potentielle fordele ved Rousseaus DRS, der påtænker de pligter, vi har over for hinanden som beboere i en demokratisk stat.

\subsection{Lykke og politisk transformation: Et fortolkningsmæssigt problem}

I første del fremlagde jeg en bekymring vedrørende den potentielle uforenlighed mellem individuel frihed og kollektiv trivsel $i$ form af en dikotomi, vi har arvet fra Kants politiske filosofi. Herved risikerede jeg en anakronisme ved at frembringe den potentielle betydning af Rousseaus DRS for os post-kantianske læsere af Rousseau. Men det gør jeg ikke nødvendigvis, for som jeg også netop har antydet, opstår de samme problemstillinger indefra i Samfundskontrakten selv. Lad mig nu forklare, hvorfor passagerne omhandlende lykke ved første øjekast fremstår som uoverensstemmende med målene for kontrakten.

Som bekendt lokaliserer Rousseau i Samfundskontrakten kilden til politisk forpligtigelse i individuelle viljers frie engagement. Rousseau antager, at kontraktens parter har: (a) en interesse i uafhængighed og (b) kapacitet til instrumentel fornuft. Betingelse (a) er en interesse $\mathrm{i} i k k e$ at være underlagt en andens vilje. Under den præ-kontraktuelle fase manifesterer dette sig som en trang til selvtilstrækkelighed, hvor selvtiltrækkelighed skal forstås på en ganske intuitiv måde som et liv, der grundlæggende ikke er samarbejdsvilligt (om end også ikke fjendtligt indstillet). Betingelse (b) antager at de præ-kontraktuelle parter kan finde ud af, hvad der kræves for at imødekomme deres basale behov således, at de kan undgå at placere sig i relationer, hvor de er afhængige af andres viljer (SC, 1.2.2). Senere lærer vi at under de nødvendige betingelser for socialt samvirke eller gensidig afhængighed, skal betingelse (a) antage formen af frihed som selvvalgt underkastelse under den universelle lov (lad os kalde denne betingelse $\mathrm{a}^{1}$ ). Rousseau behandler ofte (a) som konstitutivt for 
menneskets essentielle uafhrengighed (fx SC, 1.2.1, 1.4.7, 2.4.10, og passim) og ( $\mathrm{a}^{1}$ ) som frihed (fx. SC, 1.8.3). ${ }^{22}$

Rousseau argumenterer, at under betingelser af nødvendig indbyrdes social afhængighed og den ledsagende trussel om tabet af uafhængighed, vil kontraktens parter blive enige om en form for social organisation, i hvilken autoritet er baseret udelukkende på hver enkelt individs samtykke til at blive styret af alle. Men hvis faren er, at de sociale betingelser har skabt en situation, hvori hvert individs kapacitet til at forblive herre over sine egne kræfter er truet, hvordan kan det være en løsning at enhver opgiver kræfterne fuldstændigt? Ville det ikke være bedre at bevare den smule man har tilbage, for at forskanse sig selv i alles krig mod alle? Eftersom den basale opgave er at bevare individets ikke-afhængighed af en andens vilje under på betingelse af nødvendig (gensidig) afhængighed, skal den afhængighed, der er frembragt ved skabelsen af et kollektivt organ, være af en anderledes natur end den afhængighed, som sætter behovet for et politisk samfund i bevægelse.

Dette er kun muligt, hvis hvert individ giver afkald på sin magt i medieret form. I skabelsen af kontrakten opgiver vi samlet set kun de kræfter, som er nødvendige for, at den kollektive sammenslutning kan trives (SC, 2.4.3). Ved at give den magt til alle, har vi givet dem til hver enkelt. Hvis det endvidere er betingelserne (a) og (b) der har ledt os til at rejse statens magt, er denne magt kun legitim såfremt den ikke udtrykker enhver individuel viljes arbitrære afhængighed af en andens vilje (eller en gruppes vilje). Kollektiv magt kan derfor kun tage form af lov, en tilstand af autoritet som er ikke-arbitrær, fordi den er upersonlig (fx SC, 1.7, 2.6; DPE, 10). Måden at forblive uafhængig under betingelse af nødvendig afhængighed er at være regeret af selv-villede, universelle love: At gå fra blot uafhængighed til sand frihed. Og ved at blive fri ser vi, at vores forpligtelse til at adlyde lovene stammer fra den nødvendige brug af vores rationelle kapaciteter under betingelse af gensidig afhængighed (SC, 1.8.3).

Når man forbliver inden for den konceptuelle arkitektur i teksten, rejser der sig et dybtliggende påtrængende spørgsmål. Givet alt, hvad der er blevet sagt indtil nu, ser frihedsinstitutionen som lov nu ud til ikke at være andet end en løsning på et problem om kollektiv egeninteresse. ${ }^{23}$ Men som Rousseau bemærker i Afhandling om ulighedens oprindelse og grundlaggelse blandt menneskene, havde selv det præ-politiske menneske en måde at løse problemet om uafhængighed inden for situationer med nødvendig social afhængighed. Han kunne deltage i koordinerede opgaver, når det var påkrævet (f.eks. jagt i grupper, hvis

22 Denne konceptuelle distinktion kan ikke spore Rousseaus egentlige brug af "liberté" og "indépendance." Somme tider karakteriserer liberté blot kernen i ideen om ikke-underkastelse til en andens vilje, og derfor er neutral i forhold til frihed som selvtilstrækkelighed og frihed som autonomi (f.eks., E, 84). Frederick Neuhouser's, "Freedom, Dependence, and the General Will" in Foundations, 55-81 tilbyder en enormt hjælpsom forståelse af distinktionen mellem selvstændighed og frihed.

23 CF. Gauthier. "The Social Contract as Ideology," Philosophy and Public Affairs 6 (1977): 130-164" Gauthier argumenterer for at dette I princippet er alt hvad en social kontrakt overhovedet kan blive. For en mere fortolkningsmæssig påstand i forhold til virkningen af at dette er alt hvad Rousseaus kontrakt egentlig etablerer, se John Charvet, "Rousseau, the Problem of Sovereignty, and the Limits of Political Obligation," in Rousseau and Liberty, ed. Robert Wolker (New York: St. Martin's Press, 1995), 139-51. 148-149. 
det eneste tilgængelige dyr var svært at dræbe på egen hånd), samtidig med at han undgik situationer, som gjorde ham varigt afhængig af andre (f.eks. organisering af varige jagtforeninger med rangordensrelationer). Med andre ord, det naturlige menneskes blotte evne til instrumentel eller forsigtig tankegang (betingelse b) kunne have ledt ham til at se nødvendigheden af en minimal socialitet (DOI, 163). Man kan så ræsonnere som følger: $\mathrm{Nu}$ da omstændighederne har ændret sig, dvs. nu da den eneste måde at overleve på er ved at danne ikke-fragmentariske, holdbare former for sammenslutning, har den selv samme evne til instrumentel tankegang ledt mennesket til at indse, at det ikke har noget andet valg end at være underlagt lovene, som er præmissen for denne sammenslutning. Men hvis dette er alt hvad der grundlægger samfundskontrakten, er der ingen fælles retsorden, kun en sammenkædning af grunde, der essentielt handler om en egeninteresse $i$ at tilslutte sig retsstaten.

Alligevel er dette billede ikke i overensstemmelse med hvad Rousseau siger om betydningen af kontrakten. Snarere:

Denne overgang [passage] fra naturtilstanden til den borgerlige tilstand fremkalder en meget bemærkelsesværdig forandring i mennesket ved at erstatte instinktet med retfærdigheden i hans opførsel, og ved at give hans handlinger den moralitet, de manglede tidligere. Det er kun da, hvor pligtens stemme afløser den fysiske tilskyndelse og attråens ret [droit], at mennesket, som hidtil kun havde taget hensyn til sig selv, ser sig tvunget til at handle efter nogle principper og at rådspørge sin fornuft, før han lytter til sine tilbøjeligheder (SC, 1.8.1/ OC III, 364).

Efter at have beskrevet denne transformation begynder Rousseau at tale om livets kollektive lykke i den retfærdige statsorden. Han skriver:

De offentlige forehavender har forrangover de private i borgernes sind... for eftersom summen af den fælles lykke bidrager med en større andel til hvert individs lykke, behøver han at søge mindre efter den i sine personlige bestræbelser (SC, 3.15.3).

Ved at sætte disse to passager sammen står vi over for to nært forbundne spørgsmål: (1) Hvis meningen med kontrakten er at bevare individets interesse $i$ at forblive fri fra afhængighed af andre, hvorfor skulle muligheden for kollektiv lykke så have nogen som helst rationel tiltrækning? (2) Hvis kontrakten blot er en indikation af rationel klogskab, hvorfor kræver individer da en sådan fuldskala transformation i deres rationelle og motivationelle væsen for at acceptere den? ${ }^{24}$ Hvorfor har vi brug for at blive transformeret for at være i overensstemmelse med vores egen egeninteresse?

Vi er tilsyneladende ude af stand til at forklare Rousseaus diskussion af kollektiv lykke og politisk transformation på grund af de følgende to fortolknings forpligtigelser (FF), som vi tilfører til vores forståelse af kontrakten: 
(FF1) Qua rationel stræber kontraktens parter efter at tilfredsstille deres interesser. (FF2) Det eneste formål for og resultat af kontrakten er at sikre beskyttelsen af det enkelte individs grundlæggende interesser.

Hvis vi accepterer FF1 og FF2, forekommer det mere i overensstemmelse med ånden og formålet med kontrakten at diskutere det politiske liv som en bevægelse fra enfoldighed til en dannet egeninteresse eller langsigtet klogskab (snarere end til retfærdighed eller pligt), og fra individuel uafhængighed til delt sikkerhed (snarere end til lykke). Af alle SAs tilhængere vedkender Neuhouser sig tydeligst måden, givet FF1 og FF2, hvorpå den generelle kohærens af Rousseaus fremstilling af transformation bliver suspekt. Han skriver:

Det er en ingen beskeden afstand, der adskiller beboerne fra naturtilstandens mennesker, hvor sigtet kun er deres eget partikulære gode, fra væsner der konsekvent vil det fælles gode, fordi de anerkender at deres egen fundamentale interesse er bedst tjent ved at handle således... alligevel imødekommer denne subjektive forandring, uanset hvor væsentlig, ikke den radikale forandring Rousseau mener er påkrævet, hvis de naturlige mennesker... skal blive transformeret til borgere. For de sidstnævnte... betragter logisk set det gode for det politiske fællesskab som forudgående for deres eget, de vil det for dets egen skyld og ikke blot som et middel til at tilfredsstille interesser de har som individer. ${ }^{25}$

Neuhouser bemærker herefter eksplicit forbindelsen mellem Rousseaus diskussion af transformation, hvorved vi kommer til en forståelse af det fælles gode som forudgående for vort eget, og af Rousseaus bemærkninger om lykke. Han foreslår, at temaet om transformation "antydes i Rousseaus tale om 'fælles lykke'". ${ }^{26}$

Som jeg nævnte ovenfor forsøger SA at løse dette fortolkningsmæssige problem ved at påstå, at Rousseau i sin diskussion af lykke uforvarende udelader forskellen mellem to undersøgelsesdomæner, som bør holdes adskilt. Det første sæt af bekymringer vedrører indholdet og det normative grundlag for de krav, som nydes i et samfund, der beskytter den enkeltes frihed. Det andet sæt af bekymringer vedrører de psykologiske og pædagogiske midler, der er nødvendige for at sikre, at agenter tager sig af at regulere deres egen adfærd i lyset af disse krav. Det første sæt af bekymringer vedrører legitimitet, den anden stabilitet. Ved at udskille "betingelser for stabiliteten af et legitimt system" fra "forståelsen af legitimitet i sig selv, " eller ved at sætte lykke ved siden af det "affektive bånd", som borgere må have til hinanden og ikke ved siden af den rationelle retfærdiggørelse af politiske principper, kan SA redde Rousseau som en ren kantiansk frihedsfilosof. ${ }^{27}$

Imod dette domesticerende træk argumenterer jeg, at lykkens rolle i Rousseaus politiske teori ikke kun fungerer som en påmindelse om stabilitet; det er ikke blot en tilslutning til den menneskelige naturs realiteter. ${ }^{28}$ Snarere er Rousseaus synpunkt at statens rationelle autoritet stammer både fra sin status som selvgenereret eller autonomt vakt $\mathrm{g}$ fra bidraget

25 Foundations, 190-191 (Original kursivering).

26 Foundations, 320.

27 De to første citater er fra Cohen, Free Community, 57, det fra Neuhouser, Foundations, 192.

28 C.f. Specielt Rawls, Lectures, 193. 
den giver til menneskelig trivsel. ${ }^{29}$ Spørgsmålet om, hvorfor vi bør adlyde lovene går åbenlyst konceptuelt forud for spørgsmålet om, hvordan vi måske kunne være motiverede til at handle som vi bør, og således gør tilstedeværelsen af eudaimonistiske temaer i Rousseaus svar på førstnævnte gør lykke central, snarere end perifer for "opfattelsen af legitimitet i sig selv".

På sit højeste niveau er min anke, at SAs antagelse at Rousseau skelner konceptuel retfærdiggørelse fra en fremstilling af psykologisk motivation, er afhængig af at importere en kantiansk filosofisk sensibilitet, som er ganske fremmed for hans værk. Trods alt sigter det berømte indledende afsnit i Samfundskontrakten efter at levere en fremstilling af den retfærdige regeringsform, som absolut ikke anerkender distinktionen mellem formel legitimitet og motivationsskabende mulighed, dvs. mellem hvad "retten tillader og... interessen foreskriver" (SC, 1.1.1.). ${ }^{30}$

Overvej også at Rousseaus Émile er en udvidet meditation over, hvordan et godt, frit og pligttro liv bør se ud, ved omhyggeligt at forsøge på at vise, at sådan et liv ville være psykologisk berigende og motivationsmæssigt plausibelt for individet, som lever det. ${ }^{31}$ Derimod, hvis det at reagere på formodede normative krav, skaber en uløselig og varig splittelse i Émile (det paradigmatiske velopdragede subjekt) - dvs. hvis der på ingen måde er kontinuerlighed med den naturlige udvikling af Émiles psykologiske dispositioner - så er et sådant krav ikke ægte normativt og repræsenterer i stedet kun en art social falskhed, hvad Rousseau ofte karakteriserer som blot 'mening'.

Faktisk bliver den normative rolle af overvejelser om kollektiv lykke helt tydelig, når vi vender os mod Savojiske præsts "Trosbekendelse". Præsten siger:

29 SA's afvisning af samtykke til den eudaimonistiske dimension af forpligtelse er også historisk unøjagtig. Men efter de klassiske naturlovteoriers storhedstid, sporede moderne prækantianske personer, som for eksempel Samuel Pufendorf, moralens normativitet og politiske forpligtelser til overvejelser over vores kollektive offentlige natur, og derpå til lykke og til de lovgivende handlinger fra autoritative lovgivere, både menneskelige og guddommelige. Denne pufendorfianske (og lockeianske) tanke fremkommer i de overbevisninger figurer som St. Preux, Julie, og den Savojiske præst deler om at Guds interesse i menneskelig trivsel tjener som garantien for retfærdigheden af hans påbud (fx., J, 292-295, 311; E, 283-285). For en repræsentativ passage af Pufendorf, se The Whole Duty of Man, According to the Law of Nature, trans. David Saunders (Indianapolis: Idiana: Liberty Fund 2003), 91.

30 Ydermere er undertitlen til hele værket "Principper vedrørende Politisk Ret ", hvilket indikerer at alle aspekter af Rousseaus efterfølgende diskussion falder ind under et principielt domæne. Dette er ikke for at afvise, at han giver detaljerede fremstillinger af motivation eller stabilitet. Men det er for at afvise, at han betragter sådanne diskussioner som adskilte fra principielle spørgsmål.

31 Som St. Preux beskriver det i Julie, bør man nemlig i hævdelsen af det dydige liv give "ingen anden definition af dyder end en samling af dydige folk" (J, 48). En tidligere generation af kommentatorer som eksempelvis Judith Shklar havde derfor ret i at fremhæve centraliteten af Rousseaus moralpsykologi i hans fremstilling af grundlaget for moralsk autoritet. Shklar skriver, at Rousseaus moralargumenter baserer enhver mulig konstellation af pligter på "generelt fælles psykiske tilbøjeligheder" eller "psykiske behov". Se Shklar, Men and Citizens, 58 and 5 (henholdsvis). Mere nyligt skriver Timothy O'Hagan, "Rousseau til forskel fra Kant, er ikke optaget af at sætte etiske spørgsmål om vores pligter i absolut karantæne fra psykologiske spørgsmål om hjertets drivkræfter“. See O'Hagan, Timothy, Rousseau (New York: Routledge, 1999), 31. 
Hvis det er sandt at det gode er godt, må det være således i vores hjertes dybde såvel som i vores handlinger og den primære belønning for retfærdighed er at føle [sentir] at man praktiserer det. Hvis moralsk godhed er i overensstemmelse med vores natur, kan mennesket kun vare åndeligt sundt eller vel beskaffent i det omfang at det er godt (E, 287/OC I, 595) (min kursivering). ${ }^{32}$

Skønt der her tales om moral og ikke politisk forpligtelse, forbinder denne passage tydeligt det at handle rigtigt med at leve et sundt, genkendeligt anerkendelsesværdigt menneskeligt, og således et liv i lykke eller trivsel..$^{33}$ Moralitetens normer retfærdiggøres ved at demonstrere for hver agent, at der for denne agent kan angives, at moralske handlinger er godt for hende. Desuden ser vi her, at ved at knytte en intim forbindelse mellem moralitet og menneskelig natur opererer Rousseau utvivlsomt med et billede af lykke eller menneskelig trivsel, der er tættere på den græske forståelse af eudaimonia end på de moderne subjektivistiske fremstilling af lykke som tilfredsstillelse af præferencer. ${ }^{34}$ Givet den rolle som trivsel spiller i Rousseaus redegørelse for grundlaget af den moralske autoritet i Émile, bør man ikke konkludere at idealet om lykke, i denne specifikke politiske henseende, er udefrakommende i forhold til retfærdiggørelsen af statens normative legitimitet.

I næste del udforsker jeg en anden, mere tilfredsstillende måde at redegøre for Rousseaus bemærkninger om nødvendigheden af politisk transformation og den kollektive lykkes normative rolle. I store træk er min strategi at opgive FF2, påstanden om at det eneste formål og resultat af kontrakten er at sikre hvert enkelt individ beskyttelsen af sine fundamentale interesser.

32 Denne passage optræder for første gang i Rousseaus Moral breve, som blev skrevet med Rousseaus egen stemme, frem for præstens. For mere om lykke eller trivsel, der omfatter moralske relationer se $D O I, 187 ; L D, 16 ; E, 177,288$; J, 185, 433; ML, 79, 99; PF, 40-42; R, 75.

33 Men det ville være ekstremt besynderligt for tænkeren, som insisterede på, at "dem som vil behandle politik og moral adskilt vil aldrig forstå noget som helst af nogen af de to" (E, 235), at fastholde, at der er nogen form for fundamental diskontinuitet mellem de rationelle fundamenter for moralsk og politisk forpligtelse.

34 På den anden side, Rousseau adopterer ikke blot det såkaldte «funktionsargument» fra Aristoteles og Platon. Menneskelig trivsel er ikke defineret udelukkende i form af overvejelser om den menneskelige livsform, dvs. af hvad, der gavner et menneske som sådan ( $\mathrm{fx}$, Aristotle. Nicomachean Ethics, trans. Sarah Broadie and Christopher Rowe (Oxford: Oxford University Press, 2002), 1097b25-1098a20, og Plato. Republic, 2 ${ }^{\text {nd }}$ Edition, trans. G.M.A. Grube and C.D.C. Reeve (Indianapolis: Hackett, 1992), 352e-354a). Snarere har Rousseaus begreb om lykke et mere tydeligt demarkeret subjektivt element. Lykke er dynamisk overensstemmelse mellem hvad man kan gøre og hvad man vil, hvor det man kan ikke udelukkende refererer til hvad man har tendens til at gøre, men også til essentielle menneskelige evner (dvs. til hvad der ligger i vores natur at gøre), og hvor det man vil referer til både subjektive tilstande og til en normative opfattelse af personen (dvs. hvad man bør ville). (fx, E, 80; DOI, 118). 


\subsection{Lovgiveren og den borgerlige religion}

Rousseaus diskussion af lovgiveren er en af de dele af Samfundskontrakten, som er sværest at forene med SA. I forklaring på nødvendigheden af denne tilsyneladende overjordiske skikkelse, som sætter bevægelse i muligheden for et retfærdigt samfund, skriver Rousseau:

Idet hvert individ ikke værdsætter andre styreformer, end den der har direkte indflydelse på hans egen interesse, har han vanskeligt ved at se de fordele, som han måtte have af de bestandige afsavn, som de gode love pålægger dem. For at et folk i sin vorden kan værdsætte politikkens sunde maksimer og følge statsfornuftens grundlæggende regler, må virkningen blive til årsag, den samfundsånd, som er forfatningens værk, ville være nødt til at præsidere over selve institutionen, og mennesket ville være nødt til blive hvad det skal være, og mennesket ville forud for lovene skulle være det, som de burde blive gennem lovene (SC, 2.7.9).

For at gentage hvad der efterhånden er en noget slidt pointe: Hvis omfanget af det politiske liv er udtømt ved beskyttelsen af hvert individs grundlæggende interesser, er det helt igennem uklart, hvorfor det ville være nødvendigt for disse individer at blive transformeret i det omfang forslået her. Det eneste SA kan tilbyde i forsøget på en redegørelse for lovgiverens rolle er, at Rousseau har til hensigt at vise, at kravene om at regulere ens handlinger gennem lovgivning - selv love eksplicit designet til at beskytte individets egne (og alle andres) grundlæggende interesser - er så strenge, så modstridende med vores naturlige tendenser til egeninteresse, at det er et deskriptivt faktum at juridisk myndighed kun kan fungere, hvis individerne udvikler stærke fællesskabsmæssige og borgerlige bånd til deres medborgere.

Jeg foreslår derimod, at vi tager denne passage som den er skrevet. Som Rousseau antyder de "bestandige afsavn pålagt af gode love" medfører en form for politisk organisation ("en styreform"), som sigter mod noget mere end beskyttelse af hvert enkelt individs grundlæggende interesser. Det er derfor, at individer, forud for deres politiske transformation, har så svært ved at "værdsætte" en sådan styreform. Hvis det er således, er vi nødt til at forstå retsordensinstitutionen, der beskytter den enkeltes grundlæggende interesser, som et springbræt til et anderledes billede af det borgerlige liv. I en situation, hvor "de offentlige anliggender i borgernes bevidsthed har forrang frem for de private", er borgerne således, at deres lykke er stærkt delt og fælles, ikke forankret i tilfredsstillelsen af deres egne grundlæggende interesser. Således ser det ud til at der fra Rousseaus redegørelse af lovgiveren opstår, to distinkte sæt af forpligtelser, begge grundlagt i statens legitimitet. For det første er der forpligtelsen alene at respektere ens medborgeres fundamentale interesser, fordi en sådan respekt er nødvendig for at sikre beskyttelsen af ens egne grundlæggende interesser. For det andet er der en forpligtelse - eller i det mindste et påbud - om at blive den slags person, som opfatter sin lykke stedfæstet primært i den fælles lykke. Forpligtelsen til at blive en sådan person ser bestemt ud til at være langt fra forpligtelsen til blot at respektere sine medborgeres grundlæggende interesser. Vi kunne sige, at lovgiveren ansporer bor- 
gerne til en ny forståelse for deres egen trivsel. Som sådan begynder transformationens sprog at give mere mening.

Overvej herefter Rousseaus diskussion af den borgerlige religion. Tæt mod slutningen af værket foreslår Rousseau, at en velordnet stat ikke kan vedkende sig den kristne tro, siden denne i sin reneste form (evangeliernes religion) ødelægger enhver jordisk loyalitet og i sin urene form (romersk katolicisme) opdeler den loyaliteten i det jordiske og det guddommelige. Hvad der i stedet behøves, er en rent borgerlig religion, som mobiliserer det guddommeliges autoritet udelukkende for at bestyrke kærligheden til pligten blandt hvert statsborgligt medlem (SC, 4.8.32).

Igen, hvis man negligere statens eudaimonistiske rolle og fortolker samfundskontrakten som udelukkende sigtende mod beskyttelsen af den individuelle frihed, vil den borgerlige religion være fuldstændig malplaceret. Eller den vil i bedste fald synes kun at sigte mod indprentning af vaner blandt statsborgerne, som stabiliserer eller muliggøre lydighed over for pligten som resultatet af suveræn autoritet..$^{35}$ Dog, at fortolke den borgerlige religion som en rent motiverende kraft, ignorerer det vigtige faktum, at Rousseau tydeligt forbinder dens specifikke indhold med effekten af borgerens egen suveræne magt. ${ }^{36}$ Rousseau skriver:

Der er... en ren borgerlig trosbekendelse, hvis bestemmelse det tilkommer suvercenen at fastlagge, ikke nøjagtig som religiøse dogmer, men som følelser for det sociale, uden hvilke det hverken er muligt at være en god borger eller en tro undersåt (SC, 4.8.32) (min kursivering).

Som vi ved fra mange pointer i teksten, er suverænen ikke andet end folket, og den kan kun udtrykke sig selv i form af lov eller forpligtelse (fx SC, 2.6, 3.1.3, 3.12.1). Så hvis den borgerlige religion hører under suverænens lovgivning, da er folket underlagt en egentlig forpligtigelse til at indvæve individets rettigheder i det kollektivt lykkelige livs stof. Ligesom i Rousseaus diskussion af lovgiveren er det igen sådan, at forpligtigelserne, der stammer fra en formel, juridisk retssfære, der synes at få deres normative kraft fra måden, hvorpå de muliggøre kollektiv lykke.

\subsection{Pagt og kontrakt}

I et forsøg på at forstå Rousseaus bemærkninger om lykke og transformation foreslår jeg at udvikle, i mere detaljeret grad end Rousseau nogensinde selv gør, den ofte ubemærkede kontrast mellem en social pagt, som Genève manuskriptet kalder en "original pagt", og en social kontrakt. Rousseau sætter ikke altid ord på skelnen mellem pagt og kontrakt med

35 Se her Viroli, Well-Ordered Society, 208-211; Cohen, Free Community, 21-22, 57; Dent, Rousseau, 231-234; såvel som Gildin, Hilail. Rousseau's Social Contract: The Design of the Argument (Chicago: University of Chicago Press, 1983)., 186-187. Cf. Neuhouser, Rousseau's Theodicy, 251-264.

36 Vigtigheden af dette faktum er tilsløret af placeringen af diskussionen om den civil religion efter en lang diskussion af ikke-suveræne, over-juridiske mekanismer, fx tribunatet, diktaturet og censoren. 
den fornødne terminologi eller konceptuelle tydelighed, men det er en nøgle til at forstå hans komplette billede af legitimeringen af staten.

I rekonstruktionen af Rousseaus syn på denne skelnen er det, jeg vil fortælle, som følger: Pagten belyser de minimale normer angående ikke-indblanding for en mangfoldighed af fornuftige viljer. Den markerer bevægelsen fra de præ-kontraktuelle parters snævre egeninteresse til den dannede egeninteresse, som skal til for at etablere fælles normer, der sigter mod beskyttelse af alles grundlæggende friheder. Kontrakten sigter imidlertid på at indarbejde disse grænsesættende eller regulerende normer ind $\mathrm{i}$ en bredere ramme hos et fællesskab i trivsel. Den markerer bevægelsen fra den dannede egeninteresse til kollektiv lykke. Lad mig kort behandle dem begge efter tur.

Samfundspagten antager egeninteresserede individer med evnerne til instrumentel fornuft. Og det, den etablerer er i virkeligheden en slags transcendental forudsætning "aldrig... formelt udtalt, [men] overalt de samme, overalt stiltiende accepteret og anerkendt" (SC, 1.6.5) - omhandlende hvad der må være tilfældet for at sådanne individer kan leve sammen på en måde, som bevarer uafhængigheden for den enkelte: navnligt, at hver enkelt må give samtykke til regering ved lov. Men alt dette svarer til et metaprincip for legitimitet. Alt, hvad den egentlig siger er, at hvis der skal være legitim autoritet, må den udtrykke sig selv i en form, der gælder for alle og er fra alle (SC, 2.6, 4.2.5; DOI, 180). ${ }^{37}$ Dette følger ganske enkelt af at overveje betingelserne for den nødvendige gensidig afhængighed sideløbende med betingelse (a), dvs. hvert enkelt individs interesse i uafhængighed. Som Rousseau formulerer det, "den mest primitive sammenslutnings handling", pagten, etablerer blot det politiske legemes "formelle enhed" (GM, 163-164; se også SC, 2.6.1). Pagten gør det klart, at den lighed, som en hvilket som helst retsorden forudsætter, er afhængig af alles samtykke som grundlaget for legitimitet ( $\mathrm{fx} S \mathrm{SC}, 2.4 .8,4.2 .5){ }^{38}$ Pagten er således den grundlæggende handling, der indfører selve ideen om et "folk" som en agent, der dernæst kan instantieres eller udtrykkes i partikulære lovmæssige beslutninger ( $\mathrm{fx}$ SC, 1.5.2).

Pagten repræsenterer det første skridt i bevægelsen væk fra snæver egeninteresse. Eftersom hvert individ er kontraherende (eller mere præcist, pagt indgående) for under ekstrem uvished (eller generaliseret risiko) som betingelse at kunne opfyld sine grundlæggende egeninteressede behov sådan som hans naturlige styrke måles med andres, er det kun rationelt for ham at tilslutte sig en kontrakt i det kooperative projekt, hvis vilkårene for en sådan sammenslutning ikke er baseret på viden om styrke-forskelle. Ved at introducere ideen om fornuften $i$ at binde sig selv til kooperative normer, der er skabt $i$ uvidenhed om

37 For nogle meget foreløbige antagelser af denne distinktion se Levine, Andrew. The Politics of Autonomy: A Kantian Reading of the Social Contract (Amherst: University of Massachusetts Press, 1976)., 28; Freeman, Samuel. "Reason and Agreement in Social Contract Views," in Justice and the Social Contract (Oxford: Oxford University Press, 2009).

33; Neuhouser, Rousseau's Theodicy, 206-208; og især Althusser, Louis. Politics and History: Montesquieu, Rousseau, Marx, trans. Ben Brewster (New York: Verso, 2007)., 131.

38 Tanken er her, at ethvert efterfølgende sæt af normer, fx loven om flertalsstyre "forudsætter enstemmigheden mindst en gang" (SC, 1.5.3; see also 4.2.5). Med andre ord kan den grundlæggende norm for legitimitet, dvs. en regel for frembringelsen af yderligere normer kan ikke, ud fra smerten af en åbenlys regres, etablere sig selv ved flertalsafgørelser. 
egen forudgående forhandlingsmæssig fordel, lægger pagten grundlaget for, hvad der med tiden vil blive en interesse for at leve i samfund kendetegnet ved gensidighed og respekt for alle. ${ }^{39}$ Men i sig selv repræsenterer det ganske enkelt et klogt handlingsforløb givet hvert individs interesse i ikke-moralske mål.

Hvis vi kun tager samfundspagten med i vore overvejelser, er alt hvad der er tilgængelige for parterne den viden, at hvis der skal være en fællesvilje - groft sagt, evnen til at udvikle sig på baggrund af gensidighed - må den tage form af en universel lov. Og som sagen står vil det at have en fælles vilje muligvis kun indebære en villighed til at acceptere et styre ved lov som en betingelse for muligheden for at forfølge private interesser. Ved at tilslutte sig legitimitetsprincippet er egeninteressen blevet gjort dannet, men bestemt ikke transcenderet.

Det er derfor samfundspagten, i redegørelsen for det komplette billede af Rousseaus velordnede samfund, behøver supplering fra den sociale kontrakt. Dette medfører ikke nødvendigvis, at et velordnet samfund gør en faktisk kontrakt obligatorisk, ved hvilken individer sværger deres troskab til staten (selvom Rousseau i bestemte tilfælde anbefaler præcis dette). ${ }^{40}$ Snarere, mens pagten er model for den form for argumentation, der sikrer det grundlæggende formelle legitimitetsprincip, er kontrakten model for det fornuftsstyrede engagement, som er en følge af instantieringen af dette formelle princip i det politiske fællesskabs faktiske liv. I det første moment indfører "samfundspagten [dvs. pagten]" den blotte form af et "politisk legeme", som har "absolut magt over alle sine medlemmer" ( $\mathrm{fx}$ 2.4.1). I det andet moment bliver denne abstrakte magt kanaliseret videre med kontrakten, der materialiserer sig som en konkret skikkelse af en suverænitet, der styres af fællesskabets almenvilje.

Kontrakten giver en model for måden med hvilken agenter, gennem forenede brug af deres deliberative kræfter, kan specificere, hvad der præcist pålægges af abstrakte retsprincipper for det faktiske samfund, der vil blive styret ved hjælp af disse. Derved skaber disse agenter en politisk orden, hvori disse konkretiserede normer kan tjene som grundlag for konstruktionen af fællesskabs relationer, hvori hvert individ finder deres lykke i helhedens lykke. Forskellen mellem pagten og kontrakten handler i sidste ende om forskellen mellem at være enig i ideen om, at ens handlinger vil blive reguleret af en politisk institution, dvs. at man vil rette sig efter forskellige slags "fingrene væk!" regler (Rechtsstaat), og den meget mere substantielle bekræftelse af at tilhøre en livsform, der tilsyneladende er en efterkommer af polis. Men som vi vil se herunder er pointen, at eftersom kontrakten først fremkommer efter pagten, skal et fællesskab i trivsel opretholde det grundlæggende (liberale) legitimitetsprincip.

39 For en samtids redegørelse af to-trins begrundelsen bag hvad jeg betegner som distinktionen mellem pagten og kontrakten se Rawls' distinktion mellem "retfærdighedsprincipperne for den grundlæggende samfundsstruktur" og kontrakten om at "oprette en partikulær styreform". Theory of Justice, 11. Se også Rawls, John. Justice as Fairness: A Restatement. (Cambridge: Harvard University Press, 2001)., 215. Selvom Rawls' andet trin selvfølgelig ikke involverer den same grad af offentlig tilhørsforhold som det gør hos Rousseau.

40 Se for eksempel PCC, 138. 
Det må gøres fuldstændig klart, at distinktionen mellem pagten og kontrakten er rent konceptuel. Som sådan kan begge "momenter" indtræffe samtidigt. Rousseau antyder netop denne pointe ved at skrive, at "samfundspagten [som] giver det politiske legeme absolut magt over alle dets medlemmer", er den "samme magt som, styret af den almenviljen, bærer... navnet suverænitet" (SC, 2.4.1) (min kursivering). Ikke desto mindre er der to distinkte aspekter af politisk aktivitet i spil her. (1) For det første, er der etableringen af begrænsninger gennem formelle regler, der vedrører hvad individer ikke kan gøre mod hinanden, hvis de skal behandles som ligeværdige. Sådanne principper gælder for hvilket som helst og ethvert samfund, der er i stand til at have et fælles gode, der er bestemt af gensidigt samvirke og reguleres af alle. (2) For det andet, er der konstitueringen af et faktisk politisk fællesskab (et der hverken er hypotetisk eller forstillet, men som i høj grad er begrænset af rum og tid), der tager det som sine minimale trivselskriterier at hver og en af dets medlemmer skal behandles i overensstemmelse med den formelle beskyttelse af lighed som etableret i (1).

Jeg begyndte med at diskutere frihedens og trivslens rolle i Rousseaus redegørelse for statens legitimitet. Vi kan nu værdsætte, at Samfundskontraktens måde at give substans til den gensidige afhængighed mellem disse idealer igennem pagt/kontrakt distinktionen også giver anledning til en todelt redegørelse for de forpligtelser borgerne skylder hinanden. Den første komponent vedrørende forpligtelse, som er institutionaliseret af samfundspagten, følger helt enkelt af overvejelser omkring en pluralitet af rationelle viljer, frie (dvs. uafhængige) og klogskabsmæssigt egeninteresserede, under gensidighedens betingelser. Og hvad den etablerer er mestendels negativt: At enhver bør rette sig efter love, der påbyder lige behandling. I kontrast hertil muliggør pagten fremkomsten af et meget mere robust, positivt tilhørsforhold til ens medborgere. Her er ens pligt ikke blot at adlyde lovene eller endda at adlyde reglerne af den grund, at det muliggør alles frihed. Snarere er det at forstå ens eget gode som uløseligt fra den fælles aktivitet, der bestemmer helhedens gode.

\subsection{Den borgerlige religion igen}

Lad os for at få en bedre forståelse af denne, tilstået, abstrakte model, vende tilbage til den borgerlige religion. Ved at tilsidesætte Rousseaus antydninger om den kollektiv lykke er det vi hovedsaligt har set i teksten op til dette punkt, en uddybning af pagtens resultater. Det pagten gør klart er, at hvis staten skal løse problemet med at sikre individuel autonomi, må hvert individ forstå lovene som havende absolut første prioritet og altoverskyggende fornuftskabende kraft. Forstået på den måde, at individer ikke kan nægte at adlyde samvirkets normer, hvis disse af en eller anden grund ikke længere er i overensstemmelse med deres dannede egeninteresse. De må bringes til at støtte ideen om, at love, der er skabt i uvidenhed om styrkeforskelle, er gode for dem selv. Men årsagen til, at lovene er gode for dem selv er, at det er den eneste måde, hvorpå hvert individ kan forfølge sin egeninteresse fri for udefrakommende indgriben (SC, 4.1.6). 
Den indlysende konklusion på Rousseaus diskussion af den borgerlige religion er imidlertid, at han tydeligvis også mener, at et velordnet samfund kræver et yderligere og langt stærkere krav om borgerlig enhed for at "knytte borgernes hjerter til staten" (SC, 4.8.21). Her er det, at adlyde lovene for deres egen skyld, at adlyde dem, fordi de muliggør gensidig omsorg og hensyn, ikke blot fordi de forbyder udefrakommende indblanding. Men ved at hylle doktrinen om den borgerlige religions ind i suverænitetens sprog gør Rousseau krav på, at denne form for borgerlig enhed som et resultat af suverænitetsmagt, må respektere det grundlæggende mål, for hvis skyld suverænitetsmagten er indstiftet: Individets rettigheder. Rousseau udtrykker indirekte denne pointe med sin dystert-klingende påstand, at suverænen ikke kan tvinge nogen til at tro på den borgerlige religions doktrin, men kun landsforvise dem der ikke gør. Hvad dette anerkender, er at suverænitet ikke kan løbe fra den rettighedsbeskyttelse, som den nødvendigvis skylder borgerne, qua deres medlemskab af suverænen. (SC, 4.8.32).

Derfor er den til tider anstødeligt illiberale doktrin om den borgerlige religion i virkeligheden det klareste udtryk for den gensidige afhængighed mellem individuel frihed og kollektiv trivsel i Rousseaus udgave af statens rationelle autoritet og grundlaget for politisk forpligtigelse..$^{41}$ Det har vist sig, at staten må beskytte individets rettigheder for den kollektive trivsels skyld. I den forstand synes lykke at være primær. Men ægte trivsel afhænger af beskyttelsen af individernes rettigheder. I denne forstand synes frihed som autonomi at være primær. Ved at sammenstille de to, forstår vi, at ingen af dem er primære, men de medkonstituerer snarere hinanden. Rousseaus DRS viser, hvordan autonomi og lykke er internt snarere end kontingent relateret.

Ved at vise denne forbindelse undgår Rousseaus filosofi om staten Kants kritik af eudaimonistiske politiske teorier. Hvis relationen mellem rettigheder og eudaimonia er konstitutiv snarere end instrumentel, sigter rettigheder ikke mod at sikre et mål for lykken, som er defineret i ikke-moralske termer. Snarere inkluderer en komponent af det lykkelige liv beskyttelsen af rettigheder for deres egen skyld..$^{42}$ (Sagt en smule anderledes: En del af det,

41 Den stærkeste måde at redde den borgerlige religion på politisk er at påstå, at alt hvad den grundlæggende foreskriver er, at vores højeste gode findes i politisk deltagelse. Dette levner rum for den mulighed, at andre aspekter af det menneskeligt gode er plurale og ikke-stats baserede. I denne betydning er Rousseaus liberalisme stærkt omfattende, uden at den derfor bliver simpelthen illiberal

42 Her vil det muligvis være oplysende, at sammenligne Rousseaus fremstilling af lykke og frihed med Aristoteles' begreb Eudaimonia og de forskellige domæner eller aktiviteter, som tilsammen skaber et velfungerende liv. Ifølge en skelsættende artikel- af J.L. Ackrill, skal eudaimonia ikke forstås som det ultimative mål for hvilket værdifulde handlinger blot er midler. Snarere er "eudaimonia konstitueret af aktiviteter som er mål i sig selv." Ligesom fx aktiviteten at putte er en konstituerende del af at spille godt, men ikke et middel til det mål at spille golf, er dydig handling en konstituerende del af eudaimonia. Hvorvidt dette er en nøjagtig læsning af Aristoteles er irrelevant til mit formål. Det vigtige er, at Rousseaus redegørelse for relationen mellem den moralske beskyttelse af rettigheder og kollektiv trivsel er tydeligt del-hel snarere end midler-mål. Se Ackrill, J.L. "Aristotle on Eudaimonia," in Essays on Aristotle's Ethics, ed. Amélie Oksenberg Rorty (Berkeley: University of California Press, 1980), 19. (relevant er også Anscombe, Elizabeth. "On Promising and its Justice," in Ethics, Religion, and Politics: The Collected Philosophical Papers, Volume III (Minnesota: University of Minnesota Press, 1982),15). Se også Sandels påstand om, at man kan bevare ukrænkeligheden af rettigheder, mens man knytter dem til en opfattelse af det gode, så længe som dette gode består af mål med intrinsisk "moralsk vigtighed" (Liberalism and the Limits of Justice, xi). 
der gør enhver partikulær form for kollektiv trivsel værd at bevare er i første omgang, at den beskytter individets moralske autonomi). DRS bevarer tanken om, at rettigheder har altoverskyggende værdi, men den foreslår, at denne værdi stammer fra måden, hvorpå de muliggør et godt menneskeliv, et der leves i overensstemmelse med vores kollektive natur. ${ }^{43}$

Endelig, ved at forstå Rousseaus diskussioner af politisk transformation og kollektiv lykke igennem linsen der består i distinktionen pagten/kontrakten kan vi se, at vi er nødt til at opgive FF2. Det er helt enkelt ikke tilfældet, at det eneste formål med Rousseaus kontrakt er at sikre det enkelte individ beskyttelsen af hans grundlæggende interesser. Snarere, ved at sikre individuelle interesser er hensigten med kontrakten at muliggøre en form for kollektiv trivsel, omend en, der bevarer enhvers frihed.

\subsection{Frihed, amour-propre og almenviljen}

Ideen om, at Rousseaus filosofi om staten primært er en filosofi om frihed, er et dybt rodfæstet stykke af den filosofiske historie. Og derfor synes min påstand om, at den kollektive lykke spiller en retfærdiggørende rolle i Samfundskontraktens projekt, muligvis stadig suspekt. I dette afsnit tilbyder jeg et meget kort, indledende rids af, hvordan DRS er forbundet med andre aspekter af Rousseaus tænkning, - nemlig frihed som det menneskeligt gode, amour-propre og almenviljen - for at gøre det mere plausibelt. Lad mig behandle dem en ad gangen.

(1) Frihed som det menneskeligt gode. Helt åbenlyst er Rousseaus redegørelse for den kollektive trivsels natur afhængig af hans syn på den menneskelige naturs essens. Rousseau understreger denne pointe, når han skriver, at man ikke kan " forestille sig... sand lykke... for noget væsen, der står uden for dets konstitution (E, 87) (min kursivering). Men Rousseau hævder også gennem sine tekster, at essensen af menneskets natur simpelthen er frihed. Frihed siges endda sommetider at være det primære mål for menneskelig lykke (fx "lykken hos... menneskene... består i brugen af deres frihed" $(E, 85))$, og at være det centrale menneskelige gode ( $\mathrm{fx}$ frihed er det "første af alle goder" (E, 84)). Således kunne den forbindelse, jeg har insisteret på mellem frihed og trivsel, måske også beskrives som frihedens enhed set under to aspekter: Som det formelle træk ved rationel selv-lovgivning (dvs. at adlyde ingen anden vilje end min egen) og som det substantielle gode, der præger alle værdifulde komponenter $i$ et menneskeligt liv $i$ trivsel.

I denne forstand er påstanden i DRS, at frihedens formelle værdi som rationel autonomi, stammer fra den måde, hvorpå den muliggør individers deltagelse i de frihedsopfo-

43 Cf. Stephen Salkever, "Rousseau and the Concept of Happiness": Polity 11 (1978-1979): 27-45. 28, 37-38. Salkever anerkender, at Rousseau opfatter moralitet som tæt knyttet til menneskelig trivsel, men han konkluderer fejlagtigt, at rettigheder kun er instrumentelt værdifulde. Han lægger ikke mærke til den mulighed, at eudaimonia kan være konstitueret af $\mathrm{i}$-sig-selv eller intrinsisk værdifulde handlinger. I processen med at kritisere Salkevers såkaldte eudaimonistiske fortolkning går Cooper også fejl af forskellen mellem at værdsætte moralitet eller rettigheder som en del af lykke og at værdsætte den som middel til lykke. Se Cooper, Rousseau, Nature and the Problem of the Good Life, 19-29. 
strende goder i det kollektive liv. Derfor er værdien af individuelle rettigheder, at de gør det muligt for en agent at realisere goderne (og udvikle evnerne), som hidrører fra deltagelse i fx familiens tilstand, mens det sikrer ham imod truslen om at falde ned $\mathrm{i}$ afhængighedsrelationer til andre agenter. Eller for at udtrykke det mere enkelt, i denne redegørelse er en del af grunden til at staten er legitimeret, at den ved at sikre mine rettigheder tillader mig at realisere godet ved offentlig deltagelse uden at blive offer for de riges forgodtbefindende, og at tage del i familielivets gode uden, at blive offer for en paternalistiske despots arbitrære bud. Frihed som rationel autonomi muliggør frihed som social selvrealisering.

(2) Amour-propre. I nærværende artikel har jeg ikke nævnt Rousseaus fyldige diskussion af amour-propre, eller den basale menneskelige længsel efter at blive anerkendt af andre som et værende, der 'tæller' som havende social status. Dette er til dels, fordi hans eksplicitte diskussioner af dette tema forekommer i Second Discourse og Émile, ikke i Samfundskontrakten. Men en del kommentatorer har erkendt, at for Rousseau er en del af værdien af politisk lighed, at den tilfredsstiller individers længsel efter anerkendelse på en måde, der ikke leder til en følelse af overlegenhed, mindreværd og psykisk smerte. Hvis det forholder sig således, så understøtter amour-propre retfærdiggørelsen af et velordnet samfund. 44 Men så ligger en del af dens retfærdiggørende kraft i sikringen af frihed, ved at den besvarer vores behov for at blive anerkendt og draget omsorg for af andre. Dette aspekt af vores eksistens falder tydeligvis også ind under lykkens domæne. Endnu engang, individuel frihed er til for realiseringen af vores sociale naturs skyld, og retfærdiggørelsen af den frihedsbevarende stat er, at den tillader os at opleve denne sociale natur på en måde, der er selvbekræftende og således måske endda lykkelig i en mere dagligdags psykologisk forstand.

(3) Almenviljen. Jeg har også udeladt enhver form for eksplicit diskussion af det notorisk omstridte fortolkningsspørgsmål om hvordan almenviljen skal forstås. Uanset hvad den præcist er, har den noget at gøre med den grundlæggende regulering af det politiske liv gennem normer, der både gælder for og er afgjort og bestemt af alle medlemmer i fællesskabet. I kraft af den centrale rolle dette begrebspiller for Rousseaus retfærdiggørelse af staten, er det ikke overraskende, at Rousseaus diskussioner af almenviljen svinger mellem at understrege individuel frihed og kollektiv trivsel. Derfor synes almenviljen til tider simpelthen at være et spørgsmål om at abstrahere fra partikulære formål - som Rousseau udtrykker det, "de plusser og minusser, som ophæver hinanden" (SC, 2.3.2) - for at fastsætte vilkår for gensidig begrænsning på den individuelle stræben efter det gode. ${ }^{45} \mathrm{Og}$ dog fremstår den andre gange mere som et princip om aktiv deltagelse, hvor individer identificerer deres

44 For en kort skitse af denne pointe se Ripstein, Arthur. "Universal and General Wills: Hegel and Rousseau," Political Theory, vol. 22, no. 3 (1994): 444-467. Den mest imponerende uddybning af dette tema er utvivlsomt Neuhousers Rousseau's Theodicy. Faktisk fremhæver Neuhouser i dette værk ofte værdien af offentlig trivsel. Som jeg har diskuteret i en anmeldelse, er Neuhousers vidunderlige redegørelse for amour-propre I Rousseau's Theodicy faktisk i strid med hans adskillelse af stabilitet fra legitimitet i Foundations. Se min "Content, Motivation, and the Grounds of Moral Authority: On the Social Autonomy Reading of Rousseau" (under review).

45 For en kraftfuld filosofisk rekonstruktion af almenviljen som regulativt princip se Cohen, Free Community og Gopal Sreenivasan, "What is the General Will?", The Philosophical Review 109, no. 4 (2000): 545-581. 
gode som uløselig fra bestemmelsen af det gode for fællesskabet som helhed ( $f x$ SC, 3.15). Mit håb er, at DRS vil lade os se disse karakteristika som komplementære frem for modstridende, så det kan skabe et skarpere fokus på Rousseaus ellers gådefulde påstand, at almenviljen "simultant er folkets ret og kilden til dets lykke" (PF, 23) (min kursivering).

\subsection{Konklusion: Samtidig anvendelse}

Ved at redegøre for kollapset af SA's forsøg på at forklare Rousseaus retfærdiggørelse af staten, der kun bruger begreberne frihed og rationel autonomi, har jeg skabt en forbindelse mellem den individuelle autonomis rettigheder og det gode som kollektiv menneskelig trivsel. Beskyttelsen af lige rettigheder er grundlagt i vores status som rationelle, målsættende væsener. Så langt er SA korrekt. Som vi har set igennem vores diskussionen af den borgerlige religion og af lovgiveren, har lige rettigheder imidlertid vist sig at være værdifulde for det samvirkende, gensidigt afhængige liv, som de muliggør. Jeg har også argumenteret for, at vi ikke behøver at bebyrde Rousseau med den kantianske antagelse, at hvis man grundlægger værdien af pligt i lykke, derved gør rettigheder kontingente og blot valgfrie. Snarere viser DRS, at et nødvendigt, konstituerende element af offentlig trivsel er, at individer bliver behandlet som ukrænkelige rettighedssubjekter, hvilket tilskrives dem i kraft af deres status som frie og rationelle. Frihed er kun til for trivslens skyld, hvis trivslen bevarer friheden.

Hvor attraktivt dette billede end måtte være, så efterlader det os med spørgsmålet, hvilken rolle kan lykke-idealet spille i forståelsen af grundlaget for vores troskab mod faktiske stater, som oftere end det modsatte mangler en robust forståelse af det fælles gode? Her er ét forsøg at give en grov skitse af, hvad der muligvis kan påłgges af DRS i ikkeideelle tilfælde, og dermed vise Samfundskontraktens forsatte relevans for samtidig politisk teori. Overvej forskellen mellem de følgende typer af argumentationer:

(1) Jeg vil stemme for en lov, der pålægger de rige højere skatter, selvom jeg er rig. Jeg stemmer ikke for denne lov, fordi jeg kalkulerer, at hvad jeg på længere sigt mister i formue, vil blive indirekte genindtjent - fordi fx flere skatter vil lede til bedre skoler og derved et bedre uddannet og mere effektivt arbejderkorps, som jeg kan ansætte i min virksomhed. Snarere gør jeg dette, fordi en sådan lov vil imødekomme det rationelle samtykke for alle der er underlagt denne, og derfor er den retfærdig.

(2) Jeg vil støtte love og politiske kampagner, som sigter imod at sikre, at de forhøjede skatteindtægter fremsat af loven som stemt for i (1) vil blive brugt til at forbedre offentlige skoler, snarere end til at øge forsvarsbudgettet. Igen, dette skyldes ikke kun grunde, der omhandler den overordnede større nytte af et veluddannet borgerskab modstillet et up to date moderne atomforsvarsprogram. Min overbevisning er snarere baseret på en følelse af, hvad man skylder en person. Uddannelse er en del af et sæt grundlæggende rettigheder. Det er den sikkerhed og tryghed, der kommer af at leve i en stat, der kan udslette en stor del af verden med et enkelt slag, ikke. 
(3) Jeg vil tjene som en del af en forældreorganisation, der frivilligt bruger deres tid på at undervise og hjælpe med at få skolen til at fungere. Vi arbejder sammen i fællesskab, fordi jeg anskuer dit barns interesse, som mit barns interesse og vice versa - selvom mit barn går i en privat skole nede ad gaden (husk, jeg er rig). Ydermere er vore børns interesser vores alles interesser, så din interesse er en del af min interesse.

(1)-(3) repræsentere en bevægelse væk fra handlinger, der kun tilsigter at sikre formelle legitimitetsprincipper, og mod en mere robust fornemmelse af trivsel som menneskelig gensidig afhængighed, selvom (3) kommer til kort i graden af ressourcelighed og muligheder, der kræves af et velordnet samfund. I ikke-ideelle tilfælde burde Rousseau tænke, at borgernes argumenter skal være mere som (3) end som (1). Ræsonnør (3) tillader ikke kun et grundlæggende fairness princip at regulere hendes private stræben. Snarere er andres interesser blevet en del af hendes egne interesser, og derfor er hendes lykke uløselig fra helhedens lykke. Og alligevel vil hendes ræsonnementer kun syne af en ubegrundet entusiasme for fællesskabet, hvis den ikke er informeret af respekt for enhvers autonome samtykke, hvilket er det regulative ideal hos den meget mere minimalt involverede ræsonnør (1). Hensyn til individuel frihed er den muliggørende betingelse for lykke, i korrekt forstand.

Vi er ikke nødt til at acceptere, at Rousseau binder statens eudaimonistiske dimension til religion, religion selv af en borgerlig art, for at tænke, at hvis vi først har et rimeligt fair system på plads, kan vi moralsk kræve af hinanden, at vi bliver ligesom ræsonnør (3). Hvad præcist påtvinger dette påbud subjekterne i en verden, der er så helt igennem uretfærdig, at man ikke engang kan forestille sig retfærdighed som styrende, og endnu mindre offentlig trivsel? Det kan kun være en forpligtelse af troskab mod vores evne til at skabe en ny verden - en kraft der, som Samfundskontrakten lærer os, altid kun kan være vores egen.

\section{Oversat af Mathias Christensen, Dag Munk Lindemann og Emma Storgaard}




\section{Forkortelser for arbejder af Rousseau}

DOI Discourse on the Origin of Inequality, in The Discourses and Other Early Political Writings, ed. Victor Gourevitch (Cambridge: Cambridge University Press, 1997).

DPE Discourse on Political Economy, in The Social Contract and Other Later Political Writings, ed. Victor Gourevitch (Cambridge: Cambridge University Press, 1997).

E Émile, trans. Allan Bloom (New York: Basic Books, 1979).

J Julie, trans. Philip Stewart and Jean Vaché (Hanover, New Hampshire: Dartmouth College Press, 1997).

GM Geneva Manuscript, in On the Social Contract, ed. Roger Masters, trans. Judith Masters (New York: St. Martins, 1978).

LD "Letter to D’Alembert," in Jean-Jacques Rousseau: Politics and the Arts, trans. Allan Bloom (Ithaca, New York: Cornell University Press, 1960).

LM Letters Written from the Mountain, in The Collected Writings of Jean-Jacques Rousseau, Vol. 9.

ML Moral Letters, in Rousseau on Philosophy, Morality, and Religion, ed. Christopher Kelly (Hanover, New Hampshire: Dartmouth College Press, 2007).

OC Oeuvres Complètes, eds. Bernard Gagnebin and Marcel Raymond, 4 vols. (Paris: Gallimard, Bibliothèque de la Pléiade, 1959-1969).

PCC Planfora Constitution for Corsica, in The Collected Writings of Jean-Jacques Rousseau, Vol. 11, eds. Christopher Kelly and Roger Masters (Hanover, New Hampshire: Dartmouth College Press, 2005).

PF Political Fragments, in The Collected Writings of Jean-Jacques Rousseau, Vol. 4, eds. Kelly and Masters (Hanover, New Hampshire: Dartmouth College Press, 1994).

$R \quad$ The Reveries of the Solitary Walker, in The Collected Writings of Jean-Jacques Rousseau, Vol. 8, eds. Kelly and Masters (Hanover, New Hampshire: Dartmouth College Press, 2000).

SC Of the Social Contract, in The Social Contract and Other Later Political Writings, ed. Victor Gourevitch (Cambridge: Cambridge University Press, 1997). 